Research Note

\title{
EFFECT OF DIFFERENT DOSES OF NITROGEN AND PHOSPHORUS ON THE CORM AND CORMEL DEVELOPMENT OF GLADIOLUS (Gladiolus sp.) CV. AMERICAN BEAUTY
}

\author{
S. S. Pant \\ Institute of Agriculture and Animal Sciences, Rampur, Chitwan, Nepal
}

\begin{abstract}
A study was conducted to evaluate the effect of different doses of nitrogen and phosphorus on the development of corm and cormel of gladiolus at the Horticulture Farm, IAAS, Rampur in 2002. Diameter, thickness and weight of the corms, and cormels were measured after 150 days of planting and the effect of nitrogen and phosphorous fertilizers was assessed. The nitrogen dose of $50 \mathrm{~kg} / \mathrm{ha}$ produced the highest corm yield (17.71 g/plant), where as higher dose of nitrogen $(100$ and $150 \mathrm{~kg} / \mathrm{ha}$ ) fertilizer produced the lowest cormel yield. Variable doses of phosphorous did not produce any significant effect on corm diameter and corm thickness but it produced a significant effect on corm height and cormel yield per plant. Higher doses of phosphorous fertilizer (50 and $100 \mathrm{~kg} / \mathrm{ha}$ ) produced the highest yield as compared to the control. It appears that corm and cormel respond better to the higher doses of phosphorous fertilizer compared to the nitrogenous fertilizer. A significant interaction effect was observed on cormel weight. The phosphorous at $100 \mathrm{~kg} / \mathrm{ha}$ and nitrogen at $0 \mathrm{~kg} / \mathrm{ha}$ produced the highest cormel yield $(25 \mathrm{~g} / \mathrm{plant})$, whereas nitrogen at $150 \mathrm{~kg} / \mathrm{ha}$ and phosphorous at $0 \mathrm{~kg} / \mathrm{ha}$ produced the lowest cormel yield $(1.95 \mathrm{~g} / \mathrm{plant})$. The interaction effect suggests that cormel yield responds better to the higher level of phosphorous combined with lower level of nitrogen.
\end{abstract}

Key words: Nitrogen, phosphorous, corm, cormel, gladiolus

\section{INTRODUCTION}

Gladiolus is known as queen of the bulbous plants, which is valued for its beautiful flower spikes. Its cultivation is getting popular for its beautiful flowering spikes having a longer life as cut-flower. Its magnificent inflorescence with variety of colors and number of pretty florets has made it attractive for diversified use in the garden. It is an important cut-flower in both domestic and international market (Chanda et al., 2000). In Nepal, a large number of introduced varieties are available and cultivated around the cities (FAN, 1995; Pant, 2002). The application of nitrogen, phosphorus and potash plays an important role on growth, flowering and corm and cormel production. Many authors (Bhattacharjee, 1981; Borrelli, 1984; Deswal et al., 1983; Shah et al., 1984; Sindhu and Arora, 1989) have shown that an increase in nitrogen level increased the growth and greatly increased the length of flower spike and number of florets/spike. Borelli (1984) reported that increasing nitrogen supply $\left(0,10,20\right.$ or $\left.30 \mathrm{~g} / \mathrm{m}^{2}\right)$ increased the number of corms and cormels produced and higher rate of nitrogen declined in corm and cormel size associated with close spacing; however, Cirrito and Vita (1980) found that there was no relation between planting density and cormel production in gladiolus. The best results were obtained with $7.5 \mathrm{~kg}$ ammonium sulphate, $10 \mathrm{~kg}$ super phosphate and $10 \mathrm{~kg}$ muriate of potash per $100 \mathrm{~m}^{2}$ (Mishra and Singh, 1989). Higher rate of nitrogen delayed the time of flowering and increased the spike length, weight and size of the corms and number of cormels, where as higher rates of phosphorus and potash tended to improve flower quality, cormel growth and corm production in cv. Friendship (Bhattacharjee, 1981).

In the plains of Chitwan valley, cultivation of gladiolus is gaining popularity day by day. So, it is imperative to provide more information to the growers regarding application of nutrients in well-balanced ratio. Corm and cormel production plays an important role in conservation of desirable varieties for further multiplication. Hence, this study was carried out at IAAS, Horticulture Farm.

\section{MATERIALS AND METHODS}

An experiment was conducted to determine the effect of different doses of nitrogen and phosphorus on growth and development and cut-flower characteristics of gladiolus in Chitwan valley, Rampur in 2002. Field 
experiment was laid out in randomized complete block design (RCBD) with three replications. The treatments employed with different doses of nitrogen and phosphorus were twelve (Table 1). Muriate of potash was applied @ $100 \mathrm{~kg} / \mathrm{ha}$ in all the treatments.

Table 1. Treatment combination of nitrogen and phosphorus

\begin{tabular}{|cccc|}
\hline Treatments & N (kg/ha) & P (kg/ha) & Treatment combination \\
\hline 1 & 0 & 0 & N0P0 \\
2 & 0 & 100 & N0P50 \\
3 & 0 & 0 & N50P0 \\
4 & 50 & 50 & N50P50 \\
5 & 50 & 100 & N50P100 \\
6 & 50 & 0 & N100P0 \\
7 & 100 & 50 & N100P50 \\
8 & 100 & 0 & N100P100 \\
9 & 100 & 50 & N150P0 \\
11 & 150 & 100 & N150P50 \\
12 & 150 & 150 & 000 \\
\hline
\end{tabular}

The size of the plot was $1.5 \mathrm{~m}^{2}(1.5 \mathrm{~m} \times 1.0 \mathrm{~m})$ accommodating 20 plants/plot with 5 rows. The planting was done at $25 \mathrm{~cm}$ x $30 \mathrm{~cm}$ spacing on 1 February 2001. The variety adopted was American Beauty, which showed good performance in Chitwan condition (Regmi, 2000; Pakhrin, 1999).

\section{Soil sample analysis}

Soil samples were taken from $0-10 \mathrm{~cm}, 10-20 \mathrm{~cm}$ and $20-30 \mathrm{~cm}$ depth at planting time and each sample was analyzed to measure the amount of available $\mathrm{N}, \mathrm{P}$ and $\mathrm{K}$ replicating five times.

Table 2. Soil analysis report of the experimental site before application of manure and fertilizer for planting gladiolus corms

\begin{tabular}{|lcccccc|}
\hline $\begin{array}{l}\text { Depth of soil } \\
\text { samples }(\mathbf{c m})\end{array}$ & $\mathbf{O M}(\mathbf{\%})$ & $\mathbf{O C}(\mathbf{\%})$ & $\mathbf{p H}$ & $\mathbf{K}_{\mathbf{2}} \mathbf{O}(\mathbf{k g} / \mathbf{h a})$ & $\mathbf{P}_{2} \mathbf{O}_{5}(\mathbf{k g} / \mathbf{h a})$ & $\mathbf{N}(\%)$ \\
\hline $0-10$ & & & & & & \\
$10-20$ & 4.7 & 2.740 & 5.05 & 96.84 & 75.94 & 0.2534 \\
$20-30$ & 4.3 & 2.343 & 5.25 & 62.00 & 38.98 & 0.238 \\
Average value & 3.2 & 1.860 & 5.695 & 141.70 & 26.35 & 0.236 \\
\hline
\end{tabular}

$\mathrm{Om}=$ organic matter and $\mathrm{OC}=$ organic carbon

Soil analysis was done in the Central Laboratory of IAAS. Organic carbon was determined by WalkleyBlack method and multiplied by 1.72 factor to obtain organic matter. The $\mathrm{pH}$ was determined by making soil suspension (1:1 of soil and water) with the help of a direct-reading $\mathrm{pH}$ meter, using a glass electrode with a saturated potassium chloride-calomel reference electrode. The nitrogen percentage in the soil was determined with the help of Kjeldahl method in which nitrogen compounds are converted into ammonium sulphate by digestion with concentrated $\mathrm{H}_{2} \mathrm{SO}_{4}$. Phosphorous was determined by modified Olsen's bicarbonate method and the potassium was determined by flame photometer method, in which conversion factor for ppm in soil to $\mathrm{kg} / \mathrm{ha}$ is 2.24 and conversion factor for $\mathrm{P}$ to $\mathrm{P}_{2} \mathrm{O}_{5}$ is 2.3 , and conversion factor for $\mathrm{K}$ to $\mathrm{K}_{2} \mathrm{O}$ is 1.2 (Pradhan, 1996).

\section{Preparation of planting materials}

The average size of the corms was $3.15 \mathrm{~cm}(2.5$ to $3.5 \mathrm{~cm})$ diameter. Corms were prepared for planting by removing outer husk from the corm and treated with $0.2 \%$ Bavistin and Captaf for 20 minutes before planting (Singh, 1996). A uniform planting depth of $7 \mathrm{~cm}$ was maintained in all treatments and replications.

\section{Crop management}

Fertilizers were applied in the form of urea, single super phosphate and muriate of potash. Cow dung manure@10 kg/m² was applied initially. Half dose of nitrogen and full doses of phosphorus and potash were 
applied at the time of final land preparation. Remaining half dose of nitrogen was applied (top-dressed) at fourth leaf stage (Singh et al., 1994, and Chattopadhyay, 1995). Weekly irrigation was given to overcome the moisture stress. Weeding and hoeing was done at 60,80 and 110 days after planting. Last hoeing was done for corm development. Earthing up was done 90 days after planting to prevent lodging.

Multiple sprouts were removed from the plot at 50 days of planting and only single sprout was maintained to obtain standard sized spikes. Spikes were harvested (when the first floret blushed) with two broad leaves for taking observations related to spike characteristics. After 45 days of spike harvesting, the corms and cormels were harvested and diameter, thickness and weight of the corms were recorded by random samplings of five corms of each plot and the weight and number of cormels per plant also recorded for each mother corm. At the time of harvest, 6 leaves were left for corm development. When the leaves attained pale or cream color, the corm was ready for harvest. The corms were harvested after 45 days of spike harvest, i.e. 155 days of planting.

\section{RESULTS AND DISCUSSION}

Corm and cormels are the fundamental units of propagation in gladiolus cut-flower. In the present study, corm diameter, corm thickness, corm weight and cormel yield/plant were measured after 150 days of planting. The nitrogen dose of $50 \mathrm{~kg} / \mathrm{ha}$ produced the higher cormel yield $(17.71 \mathrm{~g} /$ plant) where as higher doses of nitrogen (100 and $150 \mathrm{~kg} / \mathrm{ha}$ ) fertilizer produced the lower cormel yield/plant (Table 3). Similarly, variable doses of phosphorous also did not produce any significant effect on corm diameter and corm thickness but it produced a significant effect on corm weight and cormel yield. Higher doses of phosphorous fertilizer (50 and $100 \mathrm{~kg} / \mathrm{ha}$ ) produced the highest corm weight and cormel yields as compared to the control (phosphorous 0 $\mathrm{kg} / \mathrm{ha}$ ), which produced the lowest yields of both corm and cormel (Table 3). It appears that corm and cormel respond better to the higher doses of phosphorous fertilizer as compared to the nitrogenous fertilizer.

Different response was observed on cormel yield, i.e. phosphorous@100 kg/ha without nitrogen application produced the highest cormel yield (25 g/plant) in contrast with nitrogen@ @150 kg/ha and without phosphorus produced the lowest cormel yield $(1.95 \mathrm{~g} / \mathrm{plant})$. This suggests that cormel responds better to the higher level of phosphorous. This tendency is also apparent in the development of corm yield. Haider et al. (1981) found that $50 \mathrm{~kg}$ nitrogen/ha gave the highest corm and cormel yield/plant $(142+8.6$ and $18+1.4$, respectively) over control. Mukhopadhyay (1984) found that yield of corm was higher at $100 \mathrm{~kg}$ phosphorus/ ha, i.e. at higher dose.

Table 3. Effect of different doses of nitrogen and phosphorus on the growth of corm and cormels

\begin{tabular}{|lcccc|}
\hline Nutrient $(\mathbf{k g} / \mathbf{h a})$ & Corm diameter $(\mathbf{c m})$ & Corm thickness $(\mathbf{c m})$ & Corm yield (g/plant) & Cormel yield (g/plant) \\
\hline Nitrogen & & & & $13.94 \mathrm{~b}$ \\
0 & 3.800 & 2.256 & 26.700 & $17.71 \mathrm{a}$ \\
50 & 4.011 & 2.078 & 26.189 & $7.411 \mathrm{c}$ \\
100 & 3.678 & 2.067 & 23.056 & $8.260 \mathrm{c}$ \\
150 & 3.511 & 1.922 & 2.4878 & 3.423 \\
LSD & $\mathrm{NS}$ & $\mathrm{NS}$ & $\mathrm{NS}$ & 1.167 \\
SE Mean & 0.1537 & 0.0808 & 2.4605 & 29.60 \\
CV\% & 12.30 & 11.64 & 29.29 & 0.050 \\
P value & $\mathrm{NS}$ & $\mathrm{NS}$ & $\mathrm{NS}$ & $8.387 \mathrm{~b}$ \\
Phosphorus & & & $12.41 \mathrm{a}$ \\
0 & 3.733 & 2.067 & $19.51 \mathrm{~b}$ & $14.70 \mathrm{a}$ \\
50 & 3.700 & 2.075 & $27.45 \mathrm{a}$ & 2.965 \\
100 & 3.817 & 2.100 & $28.66 \mathrm{a}$ & 1.011 \\
LSD & $\mathrm{NS}$ & $\mathrm{NS}$ & 6.250 & 29.60 \\
SE Mean & 0.1331 & 0.0699 & 2.131 & 0.050 \\
CV $\%$ & 12.30 & 11.64 & 29.29 & 0.050 \\
P value & $\mathrm{NS}$ & $\mathrm{NS}$ & & \\
\hline
\end{tabular}


Table 4. Interaction effect of different doses of nitrogen and phosphorus on the cormel weight (g) when the corms are harvested after 150 days of planting

\begin{tabular}{|lcccc|}
\hline \multirow{2}{*}{ Doses of nitrogen $(\mathbf{k g} / \mathrm{ha})$} & \multicolumn{3}{c}{ Doses of phosphorus $\mathbf{( k g} / \mathbf{h a})$} & \multirow{2}{*}{ Nitrogen mean } \\
\cline { 2 - 4 } & $\mathbf{0}$ & $\mathbf{5 0}$ & $\mathbf{1 0 0}$ & 13.94 \\
\hline 0 & $6.287 \mathrm{~cd}$ & $10.53 \mathrm{bc}$ & $25.01 \mathrm{a}$ & 17.70 \\
50 & $21.22 \mathrm{a}$ & $21.32 \mathrm{a}$ & $10.58 \mathrm{bc}$ & 7.41 \\
100 & $4.093 \mathrm{~cd}$ & $4.727 \mathrm{~cd}$ & $13.41 \mathrm{~b}$ & 8.26 \\
150 & $1.947 \mathrm{~d}$ & $13.05 \mathrm{~b}$ & $9.780 \mathrm{bc}$ & 14.69 \\
\hline
\end{tabular}

* Means in rows and columns followed by same letter do not differ significantly by DMRT at 0.05 level

\section{CONCLUSIONS}

The size of the weight of the corm is basically determined by the amount of total food stored in the corm by the plant through the process of photosynthesis. The initial plant growth and the vigor are determined by the amount of food supplied to the growing plant by the corm. Nitrogen and phosphorous fertilizers are the most essential plant nutrients for the optimum growth and development of the plant. Gladiolus is a heavy nutrient requiring cut-flower crop. Proper fertilization is needed for optimum growth and development of the plant, flower spike, florets on the spike and the underground corms and cormels, which are the food storage organs of the plant.

\section{ACKNOWLEDGEMENTS}

I express my heartily gratitude to Dr. Gopi Upreti, Dr. Durga Mani Gautam and Dr. Shanta Man Shakya for their guidance throughout experimental period and preparation of the manuscript. I am highly acknowledged to the Dean's Office for providing funds for the study.

\section{REFERENCES CITED}

Bhattacharjee, S. K. 1981. Influence of nitrogen, phosphorus, and potash fertilization on flowering and corm production in gladiolus. Singapore J. Pri. Ind. 9(1):23-27.

Borrelli, A. 1984. Planting density and nitrogen fertilizing in the cultivation of gladioli in summer and autumn. Rivista Della Ortoflorutticolura Italiana 68:201-210.

Chanda, S., G. Barma and N. Roychowdhury. 2000. Influence of different levels of nitrogen, phosphorus and potassium on growth and flowering of gladiolus. Hort. J. 13 (1): 76-86.

Chattopadhyay, T. K. 1995. Cultural requirements of gladiolus. In: K. L. Chadha and S. K. Bhattacharjee (eds.) Advances in Horticulture vol. 12 (2)- Ornamental Plants. Malhotra Publishing House, New Delhi, India. pp. 725-742.

Cirrito, M. and M. De. Vita. 1980. A comparison of three different planting densities for increasing the size of gladiolus corms. Ann. Dell. Inst. Speri. Flori. 11 (1): 169-194.

Deswal, K. S., V. K. Patil and K. W. Answrwadekar. 1983. Nutritional and plant population studies in gladiolus. Indian J. Hort. 40:254-259.

FAN. 1995. Production, packaging, marketing business plan on cut flowers carnation, chrysanthemum, gladioli, rose and tuberose. Business Plan for Cutflower Galdiolus. III vol. Floriculture Association of Nepal (FAN), Kathmandu, Nepal. 21 p.

Haider, M. M., M. V. Rao and A.S. Murty. 1981. Effects of nitrogen on growth and development of gladiolus. Indian J. Hort. 38 (3-4) : 241-245.

Mishra, R.L. and B. Singh. 1989. Gladiolus. In: T. K. Bose and L. P. Yadav (eds.) Commercial Flowers. Naya Prokash, Calcutta, India. pp. 253-267.

Mukhopadhyay, A. 1984. Nutritional studies in gladiolus cv. Vink's Glory. All India Coordinated Floriculture Improvement Project. ICAR, New Delhi, India.

Mukhopadhyay, A. 1995. Gladiolus. ICAR, New Delhi, India.

Pakhrin, D. 1999. Personal communication (a gladiolus farmer from Meghauli, Chitwan). 
Pant, S. S. 2002. Effect of different doses of nitrogen and phosphorus on growth and development, cutflower characteristics and vase-life of gladiolus cv. American Beauty. M.Sc. Thesis. IAAS, Rampur, Chitwan, Nepal.

Pradhan, S. B. 1996. Soil and plant analysis manual. NARC/The Agro-Enterprise and Technology Systems Project. USAID/HMGN, Kathmandu, Nepal.

Shah, A., S. D. Lal and J. N. Seth. 1984. Effect of different levels of nitrogen, phosphorus on growth, flowering and corm yield of gladiolus cv. Vinks Glory. Prog. Hort. 16:305-307.

Sindhu, G. S. and J. S. Arora. 1989. Response of gladiolus vars to nitrogen application. Indian J. Hort. 46:250254.

Singh, K. P., K. Sujatha, S. Uma and V. Ramachandran. 1994. Growth, flowering, yield of planting material and incidence of corm rot disease in gladiolus. Indian J. Hort. 51 (4): 408-413.

Singh, K. P. 1996. Response of whole and excised corms on production of spkies in gladiolus. Indian J. Hort. 53 (3): 228-232. 